\title{
Microbial Processes Relating to Carbon Cycling in Southeastern Bering Sea Sediments*
}

\author{
Robert P. Griffiths, Bruce A. Caldwell, William A. Broich, and Richard Y. Morita \\ Department of Microbiology and School of Oceanography, Oregon State University, Corvallis, Oregon 97331-3804, USA
}

\begin{abstract}
Several microbial variables were measured in southeastern Bering Sea sediments which should theoretically be related to carbon cycling. The variables studied included glutamate and glucose uptake and respiration rates, $\mathrm{CO}_{2}$ and methane production rates and the activities of the following hydrolases: cellulase, amylase, laminarinase, protease and xylanase. Nitrogen fixation (acetylene reduction) and denitrification rates, and phosphatase and arylsulfatase activities were also determined. The 2 regions studied were offshore sediments in the Saint George Basin (SGB) and inshore bay sediments in Port Moller (PM). Mean rates of all variables studied were higher in PM sediments when compared to SGB. The rates of methane production, $\mathrm{CO}_{2}$ production, and nitrogen fixation were comparable to those reported in temperate marine sediments indicating that these rates were not depressed because of low temperature. In sediments of both areas, phosphatase and arylsulfatase activities were highly correlated. In PM, the activity of these 2 enzymes was highly correlated with protease activity, glutamate uptake rates, and $\mathrm{CO}_{2}$ evolution rates. These correlations suggest that in PM sediments, all of these variables were interrelated and probably reflected relative levels of microbial heterotrophic activity. In the same sediments, the linear correlation between glutamate uptake rates and protease activity was very high $(r=0.993)$. This high correlation suggests that protease activity reflects amino acid availability to the microbial population as the result of protein hydrolysis. It also suggests that the glutamate uptake rates reflect the adjustment of the microbial population to levels of amino acids available in the sediments. There was a region within SGB where microbial processes were elevated during both sample periods (January and May). This area was located on an oceanographic frontal system. The high microbial activity observed there may be related to the influence of the frontal system on primary productivity and sedimentation processes.
\end{abstract}

\section{INTRODUCTION}

The southeastern Bering Sea has long supported an important Alaskan fishery, Large numbers of salmonids, demersal fish and crabs are harvested from this region annually (Bakkala et al., 1981; Otto, 1981). This high productivity reflects relatively high primary productivity by phytoplankton in the region (Goering and Iverson, 1981). The distribution of phytoplankton and utilization of the phytoplankton by zooplankton is greatly influenced by the hydrography of the region which is dominated by 3 oceanographic frontal systems. These fronts run roughly parallel to the bathymetry (Kinder and Schumacher, 1981). Between the middle front $(\mathrm{z} \cong 120 \mathrm{~m})$ and the inner front $(\mathrm{z} \cong 60 \mathrm{~m})$ there is a middle shelf zone. From the studies of Iver-

\footnotetext{
- Published as Technical Paper No. 6575, Oregon Agricultural Experiment Station
}

son et al. (1979), it was concluded that the phytoplankton settle into middle shelf sediments where they are available for utilization in the detrital food chain. Within this zone, high concentrations of infaunal organic carbon have also been observed (Haflinger, 1981). Since it is thought that most detrital carbon is cycled through bacterial biomass (Pomeroy, 1974), it was felt that by measuring microbial activity in this region, a link between the phytoplankton input and the benthic infaunal populations might be established. There are a number of possible methods for measuring microbial activity. We elected to utilize a number of these measurements in our activity determinations so that appropriate comparisons could be made.

Another objective of this study was to compare the microbial activity in the offshore sediments with the potentially productive sediments of a major bay in this region. Although there have been studies of microbial activity in the sediments of bays, estuaries and offshore 
sediments (Hanson et al., 1981), there have been no comparative studies of microbial activity in bay and offshore sediments in subarctic marine systems. Such information could lead to a better understanding of the relative importance of the detrital food chain in bay and offshore sediments.

\section{MATERIALS AND METHODS}

\section{Study Area}

The general region studied is illustrated in Fig. 1 and has been described in detail by Kinder and Schumacher (1981). This study was conducted during 2

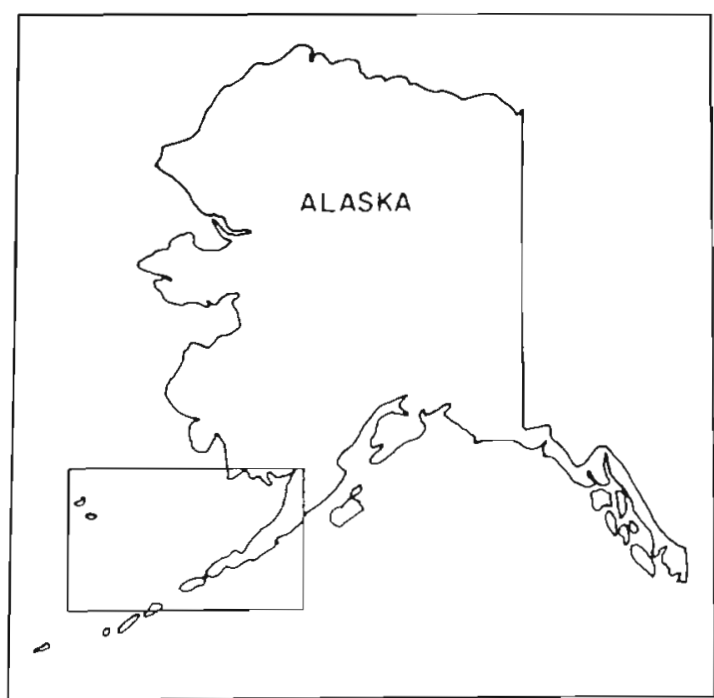

Fig. 1. Location of general study area relative to the state of Alaska

cruises in the southeastern Bering Sea (Bristol Bay), January-February 1981 and May 1981. During the January cruise, preliminary data was collected in the Saint George Basin (located in the area where the offshore stations are shown in Figs. 2 and 3). Most of the data reported in this paper were obtained from sediments collected during the May cruise at the locations shown in Figs. 2, 3, and 4.

\section{Sample Collection and Preparation}

In Saint George Basin (SGB) the sediments were collected using a Smith-MacIntyre grab sampler. Subsamples of the sediments were collected using plastic core liner $6 \mathrm{~cm}$ in diameter. The resulting cores measured approximately $10 \mathrm{~cm}$ in length. These cores were taken by slowly pushing the core liner into the sediment within the grab sampler. The top of the core liner was sealed with a rubber stopper and the core liner was slowly removed from the sediment in the sampler. The bottom of the core was then sealed with another rubber stopper. The cores were maintained within $1 \mathrm{C}^{\circ}$ of the in situ temperature until the analyses could be initiated (within 3 h). Normally, 3 cores were taken to provide enough sediment for the analyses. One of the cores was placed into a glove bag that was continuously being purged with oxygen-free nitrogen. All glassware and cores were purged before the bag was sealed. Subcores from both the bottom and top $5 \mathrm{~cm}$ were taken using $3 \mathrm{ml}$ plastic syringes with the ends cut off. Three ml of the sediment were placed into $1.6 \times 6.0 \mathrm{~cm}$ glass roll tubes while the tubes were purged with oxygen-free nitrogen and then sealed with \#00 butyl rubber stoppers (A. H. Thomas Co., Philadelphia, PA). After the roll tubes were sealed, the stopper was punctured with a syringe needle to equilibrate the headspace pressure with that of the atmosphere. The sediments in the roll tubes were used in the methane production measurements.

From the remaining cores, the top $5 \mathrm{~cm}$ was removed and mixed with enough seawater to form a thick slurry. For the $\mathrm{CO}_{2}$ production measurements, $10 \mathrm{ml}$ of this slurry was added to a $25 \mathrm{ml}$ flask and sealed with a serum bottle stopper. Samples assayed for nitrogen fixation and denitrification rates were prepared by adding $10 \mathrm{ml}$ of slurry to $60 \mathrm{ml}$ serum bottles. Samples for enzyme analysis were frozen on shipboard and returned to Oregon State University for subsequent analysis. In the ${ }^{14} \mathrm{C}$ substrate uptake experiments, $10 \mathrm{ml}$ of slurry were diluted 1,000 times using sterile seawater dilution blanks.

\section{Assay Procedures}

The procedures used to measure glucose and glutamate uptake and respiration rates have been described previously (Griffiths et al., 1977). The radioisotopes used were $\mathrm{D}-\left[\mathrm{U}-{ }^{14} \mathrm{C}\right]$ glucose, $\mathrm{L}-\left[\mathrm{U}-{ }^{14} \mathrm{C}\right]$ glutamic acid with specific activities of 328 and $10 \mathrm{mCi} \mathrm{mmol}^{-1}$ respectively and final concentrations of 3.8 and $65 \mu \mathrm{g}$ $1^{-1}$. The methods used to measure $\mathrm{CO}_{2}$ production, nitrogen fixation and denitrification rates have also been described elsewhere (Griffiths et al., 1982)

Phosphatase rate measurements were made using modifications of techniques originally described by Morita and Howe (1957) and Tabatabai and Bremner (1969). To $1 \mathrm{ml}$ of sediment slurry was added: $1 \mathrm{ml} 30$ ppt Rila Marine Mix - $0.05 \mathrm{M}$ Tris buffer, pH 7.5; and $1 \mathrm{ml}$ of $0.006 \mathrm{M} \mathrm{p}$-nitrophenylphosphate in buffer. Substrate and sediment controls were run by omitting 
either the sediment slurry or the substrate. The reaction mixture was incubated at $25^{\circ} \mathrm{C}$ for $1 \mathrm{~h}$ and then terminated with $2 \mathrm{ml} 0.5 \mathrm{~N} \mathrm{NaOH}$ and $0.5 \mathrm{ml} 0.5$ $\mathrm{MCaCl}_{2}$. The sample was then centrifuged and the optical density of the clear supernatant at $410 \mathrm{~nm}$ was measured to determine the amount of $\mathrm{p}$-nitrophenol released. A standard curve was prepared using dilutions of $10 \mu \mathrm{mol}$ per $\mathrm{ml}$ p-nitrophenol (Sigma Chemical Co). Final results were calculated as $\mu$ moles p-nitrophenol released $\mathrm{g}^{-1}$ dry weight $\mathrm{h}^{-1}$.

Arylsulfatase determinations were similarly modified for Tabatabai and Bremner (1970) and run identically to phosphatase except the substrate was $0.006 \mathrm{M}$ nitrophenyl sulfate.

Polysaccharide hydrolase assays were based on the colorimetric determination of reducing sugars enzymatically released from appropriate substrates. To $3 \mathrm{ml}$ of sediment slurry was added $3 \mathrm{ml} 30 \mathrm{ppt}$ Rila Marine Mix - $0.05 \mathrm{M}$ Tris buffer containing one of the following: $1 \%$ soluble starch, $1 \%$ carboxymethylcellulose, $0.5 \%$ laminarin, or $1 \%$ xylan. Three tenths $\mathrm{ml}$ of toluene was added to limit microbial metabolism during the assay. Substrate and sediment controls were run by omitting either the sediment slurry or the substrate. The reaction mixture was incubated at $25^{\circ} \mathrm{C}$ for $24 \mathrm{~h}$ and then centrifuged. Two $\mathrm{ml}$ of the resulting supernatant was analyzed for reducing sugars with 2,5-dinitrosalicyclic acid (Bernfeld, 1955). Final results were calculated as $\mu$ g glucose (or equivalent) released $\mathrm{g}^{-1}$ dry weight $\mathrm{h}^{-1}$.

Protease activities were determined using a modification of techniques described by Ladd and Butler (1972). One $\mathrm{ml}$ of sediment slurry was incubated with $2 \mathrm{ml}$ of $1.5 \%$ casein in $0.1 \mathrm{M}$ Tris buffer at $\mathrm{pH} 7.5$ at $25^{\circ} \mathrm{C}$. The amount of tyrosine released at 1 and 7 hours was assayed by the Folin reagent method in the above reference. Final results were calculated as nmol tyrosine released $\mathrm{g}^{-1}$ dry weight $\mathrm{h}^{-1}$ for the $6 \mathrm{~h}$ assay period.

Methane production rates were determined by assaying methane concentrations in the headspace of the roll tubes after incubation periods up to $14 \mathrm{~d}$. A
$0.5 \mathrm{ml}$ gas-tight syringe was used to remove $0.3 \mathrm{ml}$ of headspace. The concentration of methane in all tubes was determined by gas chromatography (Hewlett Packard model 5734A gas chromatograph fitted with a dual flame ionization detector). The resulting detector output was integrated using a Hewlett Packard model 3380 recording integrator. The column used was a 2 meter $\times 1 / 8$ inch stainless steel column filled with Porapak R. A helium carrier gas with a flow rate of $40 \mathrm{~cm}^{3} \mathrm{~min}^{-1}$ was used. The following zone temperatures were used in the $\mathrm{GC}$ : injection port, $150^{\circ} \mathrm{C}$; oven, $50^{\circ} \mathrm{C}$; detector, $300^{\circ} \mathrm{C}$. The integrator was calibrated using a gas standard of $100 \mathrm{ppm}$ methane in nitrogen prior to each set of measurements.

In approximately one half of the sediment samples tested, 6 subcores each were taken from the top and bottom $5 \mathrm{~cm}$ of the $10 \mathrm{~cm}$ cores. In the remaining samples, 6 subcores were taken from the top $5 \mathrm{~cm}$ only. Methane concentration measurements were made in all subcores after $1,3,5$, and $7 \mathrm{~d}$ incubation. The methanogenesis rate was the slope of the best fitting line through all 24 data points. The mean methane production rate in the top and bottom $5 \mathrm{~cm}$ was essentially the same, therefore, all methanogenesis rates were normalized to production over the entire $10 \mathrm{~cm}$ core.

All of the rates reported were normalized on a per gram dry weight bases. Two $10 \mathrm{ml}$ sediment samples were dried at $80^{\circ} \mathrm{C}$ for $12 \mathrm{~h}$ and then weighed to make the volume-to-dry-weight conversions. With the exception of the methanogenesis rate measurements where 6 subsamples were used, all other observations were made on triplicate subsamples. With the exception of the enzyme assays, all incubations were conducted in the dark within $2 \mathrm{C}^{\circ}$ of the in situ temperature. The in situ sediment temperatures during the January cruise ranged from 3.5 to $6.0^{\circ} \mathrm{C}$ (mean 4.8). During the May cruise the in situ temperatures ranged from 5.0 to $8.0^{\circ} \mathrm{C}$ in Saint George Basin (mean 6.7) and from 2.0 to $6.5^{\circ} \mathrm{C}$ in Port Moller (mean 3.4).

The statistical significance of difference was determined using the Student's " $\mathrm{t}$ " test with $\mathrm{p}$ values $\leq 0.05$

Table 1. Variables measured during January cruise in St. George Basin

\begin{tabular}{|c|c|c|c|c|}
\hline Activity & $N$ & Mean & $\mathrm{SD}^{1}$ & Range \\
\hline Glutamate uptake ${ }^{2}$ & 19 & 141 & 127 & $29-464$ \\
\hline Glutamate $\%$ resp. & 19 & 53 & 11 & $34-81$ \\
\hline Glucose uptake 2 & 18 & 11 & 9 & $2-29$ \\
\hline Glucose $\%$ resp. & 18 & 26 & 5 & $18-37$ \\
\hline Methane production ${ }^{3}$ & 25 & 0.0025 & 0.0020 & $0-\quad 0.0059$ \\
\hline $\mathrm{N}_{2}$ fixation ${ }^{4}$ & 13 & 0.1 & 0.1 & $0-\quad 0.3$ \\
\hline${ }^{1}$ Standard deviation & ${ }^{2} \mathrm{ng} \mathrm{g}^{-1} \mathrm{~h}^{-1}$ & ${ }^{3}$ nmole $\mathrm{C} \mathrm{g}^{-1} \mathrm{~h}^{-1}$ & ${ }^{4} \mathrm{ngN} \mathrm{g}{ }^{-1} \mathrm{~h}^{-1}$ & \\
\hline
\end{tabular}


considered significant. Pairwise comparisons were made on the variables to determine the linear relationship between them.

\section{RESULTS AND DISCUSSION}

This study was conducted during 2 cruises in the southeastern Bering Sea, one in January and the other in May 1981. During the January cruise, preliminary measurements were made of nitrogen fixation rates, glutamate and glucose uptake rates, and respiration percentages, and methane production rates in the Saint George Basin (SGB). Table 1 summarizes the observed values. The geographical distribution of elevated glutamate uptake rates and nitrogen fixation rates are illustrated in Fig. 2A, B. The enclosed areas represent those locations where the observed values were equal to or greater than the mean. The distribution of elevated glucose uptake rates was essentially the same as that observed with glutamate and the distribution of elevated methane production was too patchy to show a coherent pattern.

The main study was conducted during the May cruise when glutamate uptake rates and respiration percentages, nitrogen fixation rates, denitrification rates, $\mathrm{CO}_{2}$ production, methane production, phosphatase activity, arylsulfatase activity, amylase activity, and laminarinase activity were measured in SGB sediments (Table 2). The geographical regions showing elevated glutamate uptake, nitrogen fixation and $\mathrm{CO}_{2}$ production rates are illustrated in Fig. 2C, D, and E. The regions in which elevated phosphatase, arylsulfatase, amylase and laminarinase activities were observed are illustrated in Fig. 3A-D. A statistical analysis of linear
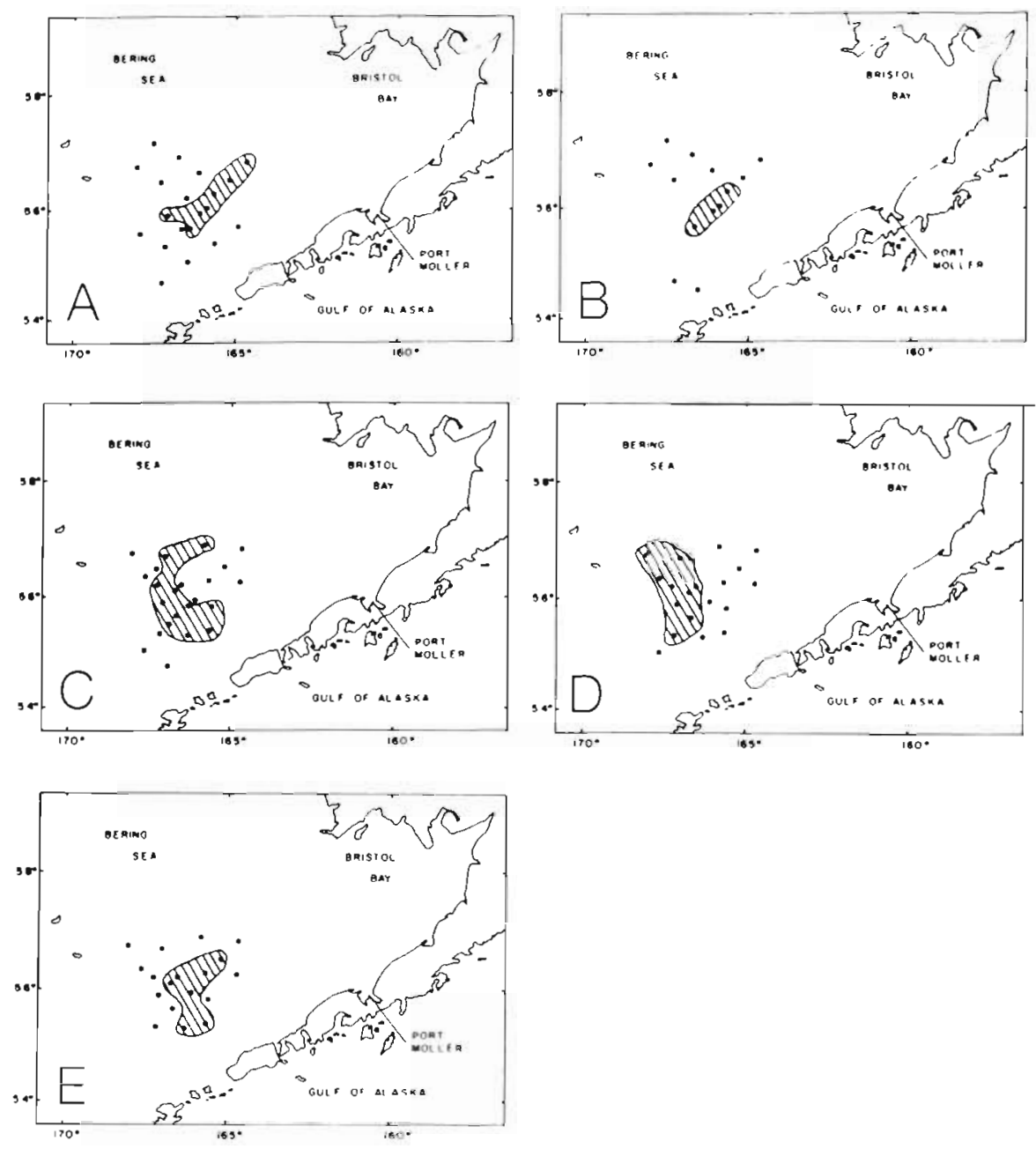

Fig. 2. Areas of elevated microbial activity. Enclosed areas: Iocations with observed values $\geq$ mean. A and B: glutamate uptake and nitrogen fixation rates respectively; January cruise. C, D, and E: glutamate uptake, nitrogen fixation and $\mathrm{CO}_{2}$ production rates respectively; May cruise 
Table 2. Comparison of microbial activities in sediments from St. George Basin and Port Moller during May cruise

\begin{tabular}{|c|c|c|c|c|c|c|c|}
\hline Activity & Location & $\mathrm{N}$ & Mean & $\mathrm{SD}^{1}$ & \multicolumn{2}{|c|}{ Range } & $\mathrm{P}^{2}<$ \\
\hline Glutamate uptake ${ }^{3}$ & $\begin{array}{l}\text { SGB } \\
\text { PM }\end{array}$ & $\begin{array}{r}23 \\
7\end{array}$ & $\begin{array}{r}215 \\
1700\end{array}$ & $\begin{array}{r}65 \\
1200\end{array}$ & $\begin{array}{l}149 \\
563\end{array}$ & $\begin{array}{l}-345 \\
-3535\end{array}$ & 0.001 \\
\hline $\mathrm{N}_{2}$ fixation $^{4}$ & $\begin{array}{l}\text { SGB } \\
\text { PM }\end{array}$ & $\begin{array}{r}19 \\
7\end{array}$ & $\begin{array}{l}0.20 \\
0.34\end{array}$ & $\begin{array}{l}0.08 \\
0.12\end{array}$ & $\begin{array}{l}0.05 \\
0.1\end{array}$ & $\begin{array}{ll}- & 0.34 \\
- & 0.5\end{array}$ & ns \\
\hline $\mathrm{CO}_{2}$ production 5 & $\begin{array}{l}\text { SGB } \\
\text { PM }\end{array}$ & $\begin{array}{r}18 \\
7\end{array}$ & $20^{2.4}$ & $\begin{array}{l}1.9 \\
15\end{array}$ & $\begin{array}{l}0.1 \\
5\end{array}$ & $\begin{array}{l}-\quad 6.2 \\
-\quad 48\end{array}$ & 0.001 \\
\hline Methane production ${ }^{5}$ & $\begin{array}{l}\text { SGB } \\
\text { PM }\end{array}$ & $\begin{array}{l}28 \\
11\end{array}$ & $\begin{array}{l}0.0039 \\
1.06\end{array}$ & $\begin{array}{l}0.0050 \\
1.06\end{array}$ & \multicolumn{2}{|c|}{$\begin{array}{ll}0.00028- & 0.019 \\
0.0011- & 2.5\end{array}$} & 0.001 \\
\hline Phosphatase ${ }^{6}$ & $\begin{array}{l}\text { SGB } \\
\text { PM }\end{array}$ & $\begin{array}{r}24 \\
7\end{array}$ & $\begin{array}{l}0.53 \\
0.94\end{array}$ & $\begin{array}{l}0.17 \\
0.40\end{array}$ & $\begin{array}{l}0.24 \\
0.39\end{array}$ & $\begin{array}{ll}- & 0.85 \\
- & 1.54\end{array}$ & 0.001 \\
\hline Arylsulfatase ${ }^{\epsilon}$ & $\begin{array}{l}\text { SGB } \\
\text { PM }\end{array}$ & $\begin{array}{r}24 \\
7\end{array}$ & $\begin{array}{l}0.63 \\
0.76\end{array}$ & $\begin{array}{l}0.27 \\
0.27\end{array}$ & $\begin{array}{l}0.20 \\
0.47\end{array}$ & $\begin{array}{l}-\quad 1.09 \\
-\quad 1.13\end{array}$ & ns \\
\hline Amylase 7 & $\begin{array}{l}\text { SGB } \\
\text { PM }\end{array}$ & $\begin{array}{r}24 \\
7\end{array}$ & $\begin{array}{l}35 \\
42\end{array}$ & $\begin{array}{l}16 \\
13\end{array}$ & $\begin{array}{l}11 \\
28\end{array}$ & $\begin{array}{l}-\quad 74 \\
-\quad 62\end{array}$ & ns \\
\hline Laminarinase ${ }^{7}$ & $\begin{array}{l}\text { SGB } \\
\text { PM }\end{array}$ & $\begin{array}{r}24 \\
7\end{array}$ & $\begin{array}{l}26 \\
98\end{array}$ & $\begin{array}{r}9 \\
28\end{array}$ & $\begin{array}{r}9 \\
59\end{array}$ & $\begin{array}{l}-\quad 47 \\
-129\end{array}$ & 0.001 \\
\hline Xylanase ${ }^{7}$ & PM & 7 & 30.2 & 9.4 & 17.6 & -47.1 & - \\
\hline Protease $^{8}$ & PM & 7 & 15.0 & 10.2 & 3.9 & $-\quad 30.4$ & - \\
\hline Cellulase $^{7}$ & PM & 7 & 16.0 & 4.0 & 11.7 & $-\quad 24.0$ & - \\
\hline 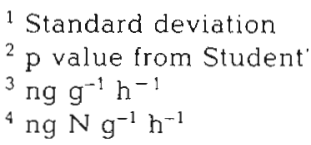 & 't' test from & $a^{2}$ & of $\mathrm{SGB}$ and & data & \multicolumn{3}{|c|}{$\begin{array}{l}{ }^{5} \mathrm{nmol} \mathrm{C} \mathrm{g}^{-1} \mathrm{~h}^{-1} \\
{ }^{6} \mathrm{umol} \mathrm{p} \text {-nitrophenol released } \mathrm{g}^{-1} \mathrm{~h}^{-1} \\
{ }^{7} \mathrm{\mu g} \text { glucose released } \mathrm{g}^{-1} \mathrm{~h}^{-1} \\
{ }^{8} \mathrm{nmol} \text { tyrosine released } \mathrm{g}^{-1} \mathrm{~h}^{-1}\end{array}$} \\
\hline
\end{tabular}
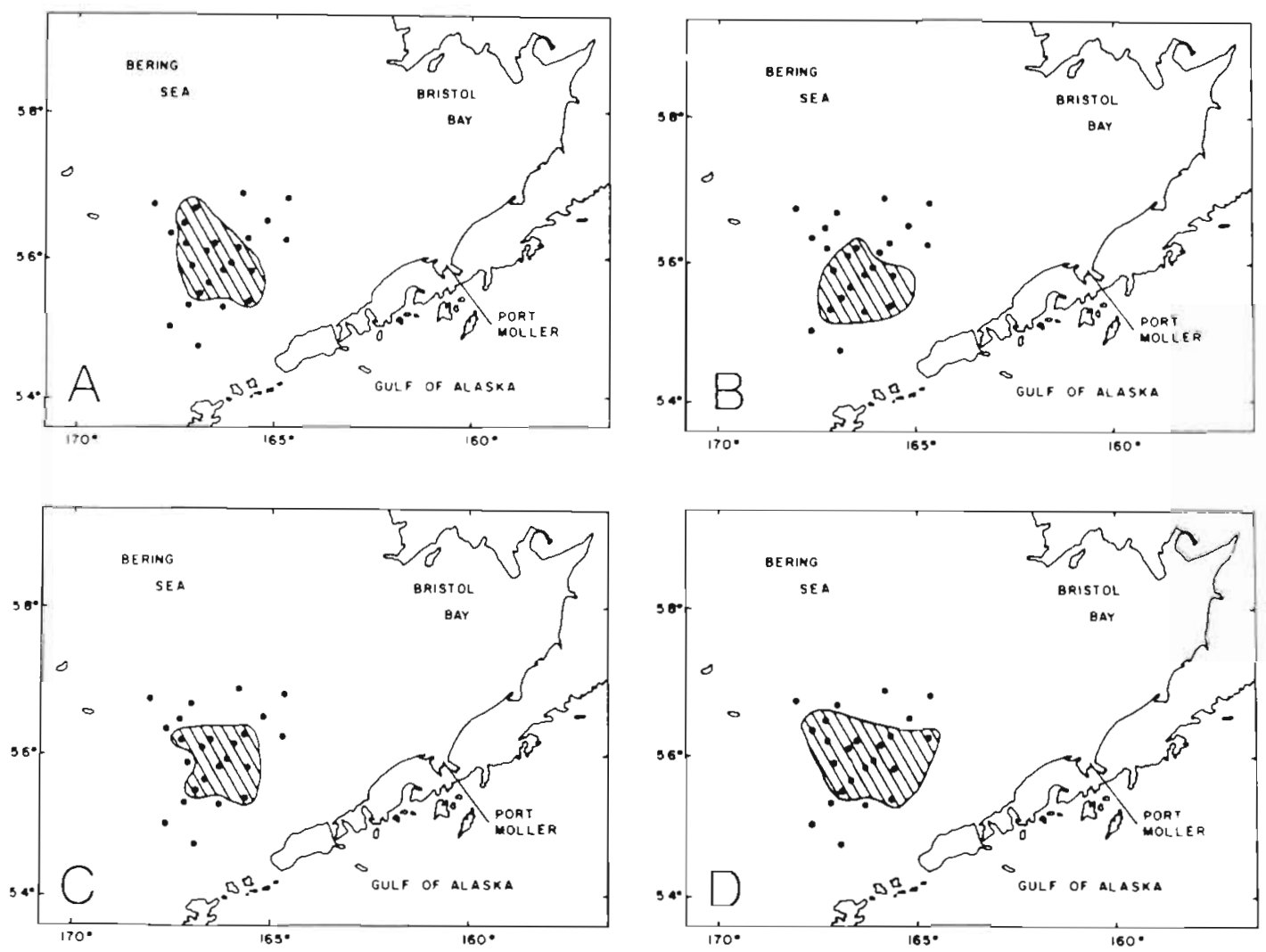

Fig. 3. Areas of elevated enzyme activities. May cruise. Enclosed areas represent locations with observed values $\geq$ mean. A, B, C, and D: phosphatase, arylsulfatase, amylase and laminarinase activities respectively 
Table 3. Correlation coefficients ( $r$ values) observed when comparing variables measured in St. George Basin. There were 22 degrees of freedom for all variables except $\mathrm{CO}_{2}$ evolution (16) and nitrogen fixation (17)

\begin{tabular}{|c|c|c|c|c|c|c|}
\hline & Phosphat. & Aryls. & Amyl. & Laminar. & $\mathrm{CO}_{2}$ & $\mathrm{~N}_{2}$ fix. \\
\hline Arylsulfatase & $0.838^{\cdots}$ & & & & & \\
\hline Amylase & $0.565^{\cdots}$ & $0.673 \cdots$ & & & & \\
\hline Laminarinase & 0.359 & $0.433^{\circ}$ & $0.608^{\cdots}$ & & & \\
\hline $\mathrm{CO}_{2}$ evolution & 0.266 & 0.218 & 0.021 & 0.254 & & \\
\hline $\mathrm{N}_{2}$ fixation & $0.572^{\cdots}$ & $0.493^{\circ}$ & 0.123 & 0.083 & 0.188 & \\
\hline Glutamate uptake & 0.144 & 0.084 & 0.002 & 0.036 & 0.030 & 0.188 \\
\hline
\end{tabular}

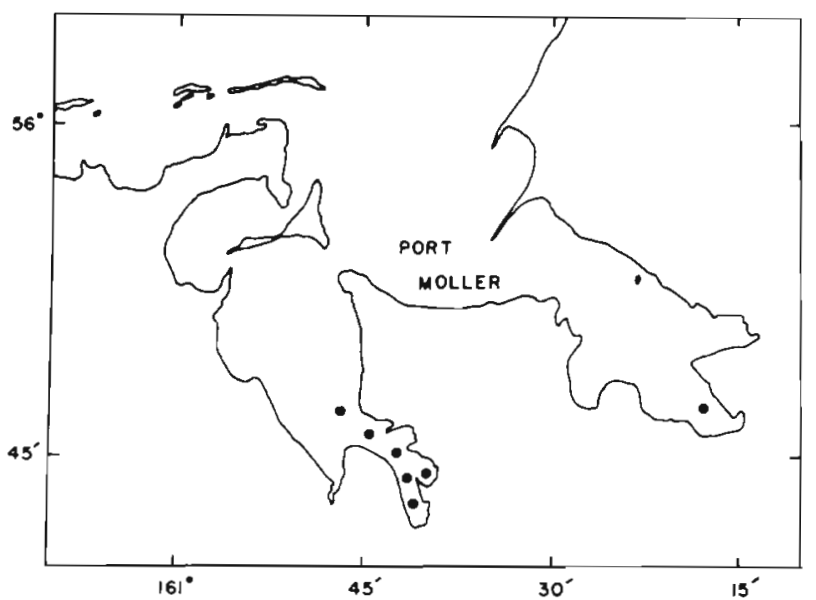

Fig. 4. Location of sample collection sites within Port Moller

correlation was made on all variables studied in SGB (Table 3). During the May cruise, we measured the above mentioned variables at 7 locations (Fig. 4) within Port Moller (PM). In addition to these variables, xylanase and protease activities were also measured (Table 2).

\section{Estimation of Total Carbon Catabolism}

We measured the release of both $\mathrm{CO}_{2}$ and methane from the sediments as a means of quantifying total carbon catabolism. Although this method does not account for the loss of carbon from the sediments through solubilization and cropping of infaunal biomass by animals not associated with the sediments, it should provide information about the total carbon catabolism in the sediments.

In $\mathrm{SGB}$ we observed $\mathrm{CO}_{2}$ production rates that ranged from 0.1 to $6.2 \mathrm{nmol} \mathrm{g}^{-1} \mathrm{~h}^{-1}$ and in $\mathrm{PM}$ the range was from 5.0 to $48 \mathrm{nmol} \mathrm{g}^{-1} \mathrm{~h}^{-1}$ (Table 2). These rates were close to those reported by others. In a study of ${ }^{14} \mathrm{C}$ labeled glucose respiration in salt marsh soils, King and Wiebe (1980) reported production rates ranging from 11 to $567 \mathrm{nmol} \mathrm{ml}^{-1} \mathrm{~h}^{-1}$. If one assumes an average density of $1.5 \mathrm{~g}$ dry wt $\mathrm{cm}^{-3}$ sediment, this range converts to 7 to $378 \mathrm{nmol} \mathrm{g}^{-1} \mathrm{~h}^{-1}$. This is comparable to the range of values that we observed in PM sediments. Hanson et al. (1981) reported a mean $\mathrm{CO}_{2}$ evolution rate in offshore sediments of $16.9 \mathrm{nmol} \mathrm{ml} \mathrm{nm}^{-1}$ $\mathrm{h}^{-1}$ (about $11.3 \mathrm{nmol} \mathrm{g}^{-1} \mathrm{~h}^{-1}$ ). This figure is higher than that observed by us in SGB but lower than the mean value observed in PM. Hargrave and Phillips (1981) estimated the net $\mathrm{CO}_{2}$ flux from a subtidal marine sediment to be 445 liter $\mathrm{CO}_{2} \mathrm{~m}^{-2} \mathrm{yr}^{-1}$. If one assumes an active $\mathrm{CO}_{2}$ production depth of $5 \mathrm{~cm}$ and a weight of $1.5 \mathrm{~g} \mathrm{ml}^{-1}$, this value becomes $7.5 \mathrm{nmol} \mathrm{g}^{-1}$ $\mathrm{h}^{-1}$ which is within the range that we observed in PM sediments.

In general, the methane production rates that we observed are also comparable to those reported by others. We observed methane production rates of $0.00028-0.019 \mathrm{nmol} C \mathrm{~g}^{-1} \mathrm{~h}^{-1}$ in SGB and $0.0011-2.5 \mathrm{nmol} \mathrm{C} \mathrm{g}^{-1} \mathrm{~h}^{-1}$ in PM (Table 2). While studying seasonal methane production rates in 'anoxic organic-rich sediments of Cape Lookout Bight', Martens and Val Klump (1980) observed rates between 49 and $163 \mu \mathrm{mol} \mathrm{m} \mathrm{m}^{-2} \mathrm{~h}^{-1}$. Using the assumptions listed above, this corresponds to a range of from 0.33 to $1.09 \mathrm{nmol} \mathrm{g}^{-1} \mathrm{~h}^{-1}$. This is close to the mean value of $1.06 \mathrm{nmol} \mathrm{g}^{-1} \mathrm{~h}^{-1}$ that we observed in PM sediments even though our mean sediment temperature was $3.4^{\circ} \mathrm{C}$ as compared to $25^{\circ} \mathrm{C}$ in the Cape Lookout Bight study. Scranton and Farrington (1977) reported a

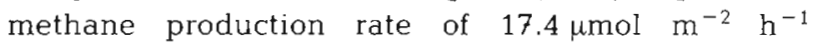
$\left(0.117 \mathrm{nmol} \mathrm{g}^{-1} \mathrm{~h}^{-1}\right)$. This value is between the mean value we observed in PM and that observed in SGB. While measuring methane production rates in shallow water tropical marine sediments, Oremland (1975) found rates approximately within the same range that we observed in SGB. Zehnder and Brock (1980) measured both methane production and oxidation in a sediment core collected from Izembek Bay which is located near PM on the Alaska Peninsula. The net methane production in the top $10 \mathrm{~cm}$ of the core was approximately $10 \mu \mathrm{mol} 10 \mathrm{ml}^{-1} 125 \mathrm{~d}^{-1}$. This is $0.22 \mathrm{nmol} \mathrm{g}^{-1}$ $\mathrm{h}^{-1}$ which is lower than the mean methane production 
rate observed by us in PM. These comparisons are useful in establishing that even though a wide range of techniques were used, the estimated rates were relatively close to those that we observed. It also serves to establish that even though the measurements were made in a large number of different sediments and generally at higher temperatures, the rates observed by us at $5.0^{\circ} \mathrm{C}$ were equivalent to those observed in temporate and tropical sediments.

\section{Potential Hydrolase Activities}

The hydrolase activities that we measured in the present study were amylase, cellulase, xylanase and laminarinase. These enzymes were selected because the substrates that they hydrolyze are potentially important structural and storage polysaccharides from both marine and terrestrial sources. Protease activity was also assayed to provide information on the potential for protein degradation. A summary of observed rates are given in Table 2 .

The methods used in this study to determine hydrolase activity did not permit the estimation of in situ hydrolase activity but did produce rates which should represent a potential rate which can be used to compare different sediments. These comparisons should reflect the input of specific compounds into the sediments. For example, if a large quantity of cellulose is incorporated into a sediment, the microbial population would start hydrolyzing that substrate to glucose. This should stimulate the growth of all glucose utilizing organisms and induce the production of more cellulase. The induced cellulase should be reflected as a higher activity in our assay. The stimulation of the appropriate hydrolase activity has been observed by us in sediments that have been amended with various compouds (unpubl.).

When the correlations among hydrolase activities and between hydrolase activity and other variables were calculated, several interesting trends emerged (Tables 3 and 4). In PM, with the exception of the cellulase-laminarinase comparison, the enzymes that hydrolyze structural polysaccharides (cellulase, laminarinase and xylanase) were significantly correlated (Table 4). Amylase, the enzyme that hydrolyzes the storage polysaccharide starch, was significantly correlated with the activities of both cellulase and xylanase. This suggests that the input of starch into these sediments may be directly related to the input of both cellulose and xylan (a pentose polysaccharide associated with plant tissue) or that all of these hydrolases are produced by the same organisms.

There was a very high correlation between protease activity and glutamate uptake rates $(r=0.993)$. A high correlation between these variables would be expected if our assumptions are correct, i.e. that the relative level of protease activity reflects protein input into the sediments. The relative levels of amino acid that result from the hydrolysis of the protein should, in turn, affect the rate at which glutamate is taken up by the microbial populations present.

The high correlation between protease activity and phosphatase and arylsulfatase activities suggest that protein input into these sediments may control the general microbial population as well as those organisms that take up glutamate. Perhaps an essential amino acid is being released during protein hydrolases. If this were the case, we would predict that the correlation between phosphatase and arylsulfatase and the activities of the enzymes that hydrolyze polysaccharides would be lower than the correlation with protease activity. This is what was observed. The correlation between protease activity and the indicator of total carbon metabolism $\left(\mathrm{CO}_{2}\right.$ production rates) was also higher than with the hydrolases. This pattern would follow from the above assumptions if $\mathrm{CO}_{2}$ evolution primarily reflects microbial respiration.

In SGB, only 2 hydrolase activities were measured. Amylase was significantly correlated with both phos-

Table 4. Correlation coefficients (r values) observed when comparing variables measured in 7 sediments collected in Port Moller

\begin{tabular}{|c|c|c|c|c|c|c|c|c|c|}
\hline & Phosphat. & Aryls. & Amyl. & Cellui. & Lamin. & Xylan. & Protea. & Glut. & $\mathrm{CO}_{2}$ Prod \\
\hline Arylsulfatase & $0.970^{\cdots}$ & & & & & & & & \\
\hline Anylase & 0.610 & 0.699 & & & & & & & \\
\hline Cellulase & 0.485 & 0.576 & $0.913^{\cdots}$ & & & & & & \\
\hline Laminarinase & $0.796^{\circ}$ & $0.808^{*}$ & 0.601 & 0.671 & & & & & \\
\hline Xylanase & 0.732 & $0.785^{\circ}$ & $0.853^{\bullet}$ & $0.923^{\cdots}$ & $0.879^{\cdots}$ & & & & \\
\hline Protease & $0.885^{\cdots}$ & $0.880^{\cdots}$ & 0.537 & 0.546 & $0.772^{*}$ & $0.791^{\circ}$ & & & \\
\hline Glutamate uptake & $0.854^{\circ}$ & $0.863^{*}$ & 0.511 & 0.546 & $0.804^{*}$ & $0.799^{\circ}$ & $0.993^{\cdots} \cdots$ & & \\
\hline $\mathrm{CO}_{2}$ evolution & $0.917^{\cdots}$ & $0.878^{\cdots}$ & 0.430 & 0.196 & 0.624 & 0.488 & 0.748 & 0.721 & \\
\hline $\mathrm{N}_{2}$ fixation & 0.452 & 0.485 & 0.081 & 0.033 & 0.003 & 0.092 & 0.560 & 0.518 & 0.450 \\
\hline
\end{tabular}


phatase and arylsulfatase activities. A similar comparison between laminarinase and the same 2 enzyme activities showed lower correlations. This is the reverse pattern from that observed in the PM sediments. These data suggest that the input of laminarin into the offshore sediments of SGB may be insignificant relative to that coming into PM sediments. The hypothesis is strengthened by the fact that the laminarinase activities in SGB were much lower than those observed in PM. There was very little difference observed in the amylase activities in the sediments of these two areas.

\section{Relative Microbial Activity}

As was the case with the hydrolases, we did not attempt to determine in situ rates of microbial activity but we did determine a potential rate that can be used to compare microbial activity in various sediments. Relative microbial activities were determined by measuring glutamate uptake and respiration rates and the activities of phosphatase and arylsulfatase. Glutamate and glucose uptake and respiration have been used to determine relative heterotrophic activities in marine waters for a number of years. More recently this approach has also been used to study the same variable in marine sediments (Christian and Wiebe, 1978; Griffiths et al., 1978; Hanson et al., 1981). The mean glutamate uptake rates that we observed during both cruises in SGB sediments were close to those observed by us in Cook Inlet sediments (Griffiths and Morita, 1981) and higher than those observed in Beaufort Sea offshore sediments (Griffiths and Morita, 1981).

The other variables measured in this study which were designed to reflect general microbial activity were phosphatase and arylsulfatase activities. Phosphatase was chosen because up to $90 \%$ of all heterotrophs isolated by Kaneko et al. (1978) from Arctic and subarctic sediments showed phosphatase activity. Kobori and Taga (1974) also observed a high percentage of marine phosphatase positive heterotrophic bacteria isolated from marine sediments collected in three Japanese Bays. While studying phosphatase in freshwater sediments, Sayler et al. (1979) observed positive correlations between phosphatase activity and both plate counts of viable bacteria and bacterial biomass as indicated by ATP levels. Phosphatase, however, is not exclusively produced by bacteria. Rivkin and Swift (1979) have documented that phosphatase can be produced by a marine dinoflagellate. Phosphatase activity has also been observed in other marine phytoplankton (Taft et al, 1977). In addition, we have observed phosphatase activity in several species of bryozoans (unpubl.).
We also measured arylsulfatase activity as an indicator of relative microbial activity. It has been hypothesized by Oshrain and Wiebe (1979) that this enzyme is produced by marine heterotrophic bacteria as a means of initiating arylsulfate ester metabolism. In both SGB and PM sediments, phosphatase and arylsulfatase activities were highly correlated which suggests that the production of these 2 enzymes is associated with related microbial populations. Both of these enzymes were also correlated to the same degree to all other variables tested which further suggests that these enzymes were present in related populations

In the PM sediments, the activities of these 2 enzymes were highly correlated with both $\mathrm{CO}_{2}$ evolution and glutamate uptake rates which suggests that all of these variables reflect heterotrophic metabolism in PM sediments. Protease was also highly correlated with these variables in PM sediments. This correlation would be expected if protein was a major component of material deposited into these sediments. This is possible because there is a major fish processing facility at the mouth of PM.

The correlation between phosphatase and arylsulfatase and both glutamate uptake and $\mathrm{CO}_{2}$ evolution rates was not observed in SGB sediments. In these sediments, glutamate uptake did not show a significant correlate with any other variable tested. It is possible that, unlike the situation in PM, protein was not a major component of the carbon input into these sediments and thus glutamate did not accurately reflect total microbial heterotrophic activity. This conclusion contradicts the hypothesis that phytoplankton (which are rich in protein) are the major source of detrital carbon in this region.

\section{Nitrogen Fixation and Denitrification Rates}

Both nitrogen fixation (acetylene reduction) and natural denitrification rates were measured in sediments during the May cruise. The denitrification levels were below the levels of detection $10.002 \mathrm{ng}$ $\mathrm{N}_{2} \mathrm{~g}^{-1} \mathrm{~h}^{-1}$ ) in all sediments studied. The nitrogen fixation rates, however, were close to those observed in marine sediments by other investigators. Hanson et al. (1981) reported a mean nitrogen fixation rate of $283 \mu \mathrm{g}$ $\mathrm{N} \mathrm{m}^{-2} \mathrm{~h}^{-1}$ in the offshore sediments that they studied. Teal et al. (1979) observed a mean nitrogen fixation rate of $330 \mu \mathrm{g} \mathrm{N} \mathrm{m}^{-2} \mathrm{~h}^{-1}$. The mean nitrogen fixation rate that we observed in SGB was $360 \mu \mathrm{g} \mathrm{N} \mathrm{m}{ }^{-2} \mathrm{~h}^{-1}$ (assuming an active nitrogen fixation depth of $5 \mathrm{~cm}$ ). The mean estimated nitrogen fixation rate in $\mathrm{PM}$ sediments was $540 \mu \mathrm{g} \mathrm{N} \mathrm{m}^{-2} \mathrm{~h}^{-1}$.

We included nitrogen fixation measurements in our study because these rates could theoretically be corre- 
lated with polysaccharide hydrolase activity. Data reported by Knowles and Wishart (1977) and Zuberer and Silver (1978) suggest that nitrogen fixation rates may be linked to the availability of glucose. If relative levels of polysaccharide hydrolase activity reflect relative fluxes of glucose in marine sediments, there could be a positive correlation between nitrogenase and hydrolase activities. During another study, a significant positive correlation was observed between amylase activity and nitrogen fixation rates in the subarctic marine sediments of Kachimak Bay, AK (Griffiths and Morita, 1981).

The lack of a significant correlation between nitrogen fixation and polysaccharide hydrolase activities in this study suggests that either our assumptions are in error or that there is some other factor involved. If there was a relatively high concentration of fixed nitrogen in these sediments, then its presence could inhibit nitrogen fixation. This could result if the detritus that settles into these sediments was high in organic nitrogen. We have already presented evidence that suggests that one of the major components of detritus entering PM sediments is protein. In SGB, Iverson et al. (1979) have concluded that the major source of detrital carbon into these sediments is in the form of phytoplankton biomass which is known to have a low carbon to nitrogen ratio. Thus the lack of correlation between nitrogen fixation and hydrolase activities in the sediments of these two areas might be explained in terms of the composition of the detritus settling into these sediments.

\section{Regions of High Microbial Activity}

Before this study was initiated, it was assumed that we would observe the highest microbial activities in areas where fine-grained sediments were present. Atlas et al. (1982) have observed this correlation in another study of subarctic marine sediments and ZoBell (1938) has also reported a correlation between numbers of viable bacteria and grain size in marine sediments. The sediment particle size distributions in SGB reported by Haflinger (1981) and the geographical distribution of elevated microbial activities observed by us suggest that this was also the case in the this region (Fig. 5). During the January cruise, there was an area A (Fig. 5) where both the glutamate uptake and nitrogen fixation rates were equal to or greater than the mean values observed in SGB. During the May cruise, these 2 variables plus $\mathrm{CO}_{2}$ production showed elevated rates in Area C (Fig. 5). During the same cruise, elevated activities for all enzymes measured were observed in Area B (Fig. 5). All of these areas overlapped in an area with the center at Station PL7 and a radius of approximately $22 \mathrm{~km}$. The center of

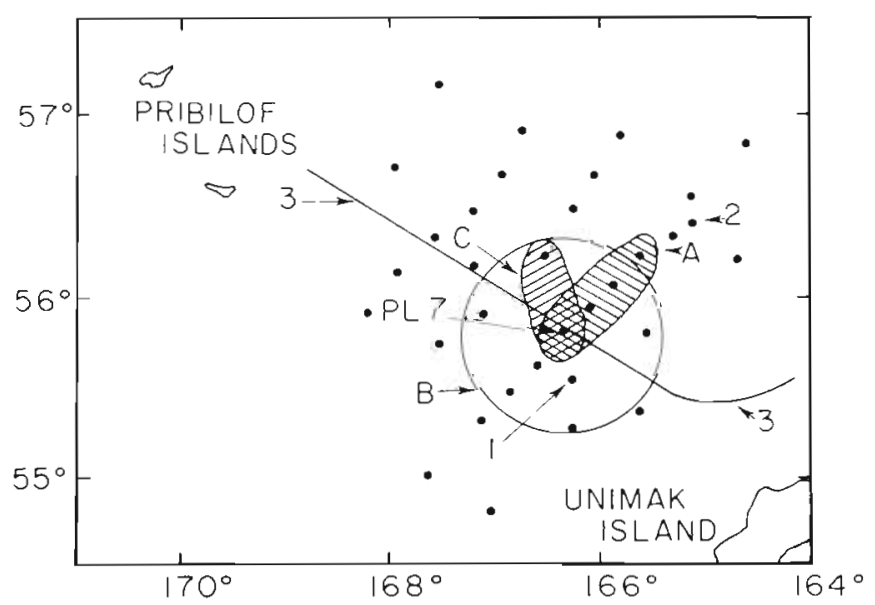

Fig. 5. Areas of elevated microbial activity in Saint George Basin with observed value $\geq$ mean. A: Area with elevated glutamate uptake and nitrogen fixation rates during January cruise. B: Phosphatase, arylsulfatase, amylase and laminarinase rates elevated during May cruise. C: glutamate uptake, nitrogen fixation, and $\mathrm{CO}_{2}$ production rates elevated during May cruise. 1: center of high silt content; and 2: center of high infaunal carbon areas, reported by Haflinger (1981). 3: approximate location of middle front as defined by Kinder and Schumacher (1981)

the area where Haflinger (1981) observed the highest sediment silt concentration was just south of PL7 (Position 1, Fig. 5).

If our measurements of microbial activity reflect relative levels of available biomass and the distribution of total infaunal biomass is directly linked to the bacterial biomass availability, we would expect that areas of high microbial activity would coincide with areas of high infaunal carbon. Haflinger (1981) measured infaunal carbon levels in SGB sediments and reported an area of elevated infaunal carbon in the sediments to the northeast of Station PL7. The center of this high infaunal carbon area is shown at Position 2 in Fig. 5. It is quite likely that the magnitude of the total infaunal biomass may be influenced by the physical composition of the sediments as well as the availability of bacterial biomass as suggested by Hanson et al. (1981). According to Haflinger (1981), the percentage of sand is greater in the area of high infaunal carbon than in the region of high microbial activity. It is possible that region of high infaunal carbon content is one that provides a suitable substrate nearest the area of high microbial productivity.

The hydrology of the southeastern Bering Sea suggests that there are 3 oceanic frontal systems that are consistent features of this region (Kinder and Schumacher, 1981). The area of highest mirobial activity lays on the middle front (Line 3 in Fig. 5). According to Goering and Iverson (1981), the area along the middle front and the waters to the northeast show high 
primary productivity rates in the resident diatom populations. Iverson et al. (1979) have hypothesized that since the water column is relatively shallow and since there are few zooplankters in the area capable of grazing on these diatoms, most of the phytoplankton biomass ends up in the sediments. The high silt content of the sediments of the area near Station PL7 reported by Haflinger (1981) suggests that there are low bottom currents in this area which would allow phytoplankton to settle into these sediments. These factors may explain why high microbial activity was observed in this area.

Acknowledgements. This research was supported by the Bureau of Land Management through interagency agreement with the National Oceanic and Atmospheric Administration (NOAA) under which a multi-year program responding to needs of petroleum development of the Alaskan Continental Shelf is managed by the Outer Continental Shelf Environmental Assessment Program Office (NOAA contract no. 03-5022-68). The authors would like to thank the crews of the NOAA ships Surveyor and Discoverer for their help.

\section{LITERATURE CITED}

Atlas, R. M., Venkatesan, M. I., Kaplan, I. R., Feely, R. A., Griffiths, R. P., Morita, R. Y (1982). Distribution of hydrocarbons and microbial populations related to sedimentation processes in Cook Inlet and Norton Sound, Alaska. Arctic (in press)

Bakkala, K. K., Hirschberger, W. (1981). Commercial use and management of demersal fish. In: Hood, D. W., Calder, J. A. (eds.) The eastern Bering Sea shelf; oceanography and resources, Vol. 2. pp. 1015-1036

Bernfeld, P. (1955). Amylases, $\alpha$ and $\beta$. In: Colowick, S. P., Kaplan, N. O. (eds.) Methods in enzymology, Vol. 1 Academic Press, New York, p. 149

Christian, R. R., Wiebe, W. J. (1978). Anaerobic microbial community metabolism in Spartina alterniflora soils. Limnol. Oceanogr. 23: 328-336

Goering, J. J., Iverson, R. L. (1981). Phytoplankton distribution on the southeastern Bering Sea shelf. In: Hood, D. W., Calder, J. A. (eds.) The eastern Bering Sea shelf: oceanography and resources. Vol. 2. pp. 933-946

Griffiths, R. P., Caldwell, B. A., Broich, William, A., Morita, $R$. Y (1982). The long-term effects of crude oil on microbial processes in subarctic marine sediments. Estuar. coast. Shelf Sci. 15: 183-198

Griffiths, R. P., Hayasaka, S. S., McNamara, T. M., Morita, R. Y. (1977). Comparison between two methods of assaying relative microbial activity in marine environments. Appl. environ. Microbiol. 34: 801-805

Griffiths, R. P., Hayasaka, S. S., McNamara, T M., Morita, R. Y (1978). Relative microbial activity and bacterial concentrations in water and sediment samples taken in the Beaufort Sea. Can. J. Microbiol. 24: 1217-1226

Griffiths, R. P., Morita, R. Y. (1981). Study of microbial activity and crude oil-microbial interactions in the waters and sediments of Cook Inlet and the Beaufort Sea. Final Report. In: Environmental assessment of the Alaskan Continental Shelf. Office of Marine Pollution Assessment/ NOAA, Juneau, Alaska

Haflinger, K. (1981). A survey of benthic infaunal com- munities of the southeastern Bering Sea shelf. In: Hood, D W. Calder, J. A. (eds.) The eastern Bering Sea Shelf: oceanography and resources, Vol. 2. pp. 1091-1103

Hanson, R. B., Tenore, K. R., Bishop, S., Chamberlain, C., Pamatmat, M. M., Tietjen, J. (1981). Benthic enrichment in the Georgia Bight related to Gulf Stream intrusions and estuarine outwelling. J. mar. Res. 39: 417-441

Hargrave, B. T., Phillips, G. A. (1981). Annual in situ carbon dioxide and oxygen flux across a subtidal marine sediment. Estuar. coast. Shelf Sci. 12: 725-737

Iverson, R. L., Coachman, L. K., Cooney, R. T., English, T S., Goering, J. J., Hunt, G. L., Jr., Macauley, M. C., McRoy, C. P., Reeburg, W. S., Whitledge, T. E. (1979). Ecological significance of fronts in the southeastern Bering Sea. In: Livingston, R. J. (ed.) Ecological processes in coastal and marine systems. Plenum Publ. Corp., New York

Kaneko, T., Haxhurst, J., Krichevsky, M., Atlas, R. M. (1978). Numerical taxonomic studies of bacteria isolated from arctic and subarctic marine environments. Microb. Ecol. 4 : 26-30

Kinder, T. H., Schumacher, J. D. (1981). Hydrographic structure over the continental shelf of the southeastern Bering Sea. In: Hood, D. W., CaIder, J. A. (eds.) The eastern Bering Sea shelf: oceanography and resources, Vol. 1. pp. $31-52$

King, G. M., Wiebe, W. J. (1980). Tracer analysis of methanogenesis in salt marsh soils. Appl. environ. Microbiol. 39: 877-881

Knowles, R., Wishart, C. (1977). Nitrogen fixation in Arctic marine sediments: effect of oil and hydrocarbon fractions. Environ. Pollut. 13: 133-149

Kobori, H., Taga, N. (1974). Phosphatase activity and its role in the mineralization of organic phosphorous in coastal sea water. J. exp. mar. Biol. Ecol. 36: 23-39

Ladd, J. N., Butler, J. H. A. (1972). Short-term assays of soil proteolytic enzyme activities using proteins and dipeptide derivatives as substrates. Soil Biol. Biochem. 4: 19-30

Martens, C. S., Val Klump, J. (1980). Biogeochemical cycling in a organic-rich coastal marine basin - I. Methane sediment-water exchange processes. Geochim. cosmochim. Acta 44: $471-490$

Morita, R. Y., Howe, R. A. (1957). Phosphatase activity by marine bacteria under hydrostatic pressure. Deep Sea Res. 4: $254-258$

Oremland, R. S. (1975). Methane production in shallowwater, tropical marine sediments. Appl. Microbiol. 30: 602-608

Oshrain, R. L., Wiebe, W. J. (1979). Arylsulfatase activity in salt marsh soils. Appl. environ. Microbiol. 38: 337-340

Otto, R. S. (1981). Eastern Bering sea crab fisheries. In: Hood, E. W. Calder, J. A. (eds.) The eastern Bering Sea shelf: oceanography and resources, Vol. 2. pp. 1037-1066

Pomeroy, W. M. (1974). The ocean's food web, a changing paradigm. Bioscience 24: 499-504

Rivkin, R. B., Swift, E. (1979). Diel and vertical patterns of alkaline phosphatase acativity in the oceanic dinoflagellate Pyrocystis noctiluca. Limnol. Oceanogr 24: 107-116

Sayler, G. S., Puziss, M., Silver, M. (1979). Alkaline phosphatase assay for freshwater sediments: application to perturbed sediment systems. Appl environ. Microbiol. 38 : 922-927

Scranton, M. I., Farrington, J. W. (1977). Methane production in the waters off Walvis Bay. J. Geophys. Res. 82: 4947-4953

Tabatabai, M. A., Bremner, J. M. (1969). Use of p-nitrophenyl phosphate for assay of soil phosphatase activity. Soil. Biol. Biochem. 1. 301-307 
Tabatabai, M. A., Bremner, J. M. (1970). Arylsulfatase activity of soil. Soil Sci. Soc. Ann. Proc. 34: 225-229

Taft, J. L., Loftus, M. E., Taylor, W. R. (1977). Phosphate uptake from phosphomonoesters by phytoplankton in the Chesapeake Bay. Limnol. Oceanogr. 22: 1012-1021

Teal, J. M., Valiela, I, Berlo, D. (1979). Nitrogen fixation by rhizosphere and free-living bacteria in salt marsh sediments. Limnol. Oceanogr. 24: 126-132
Zehnder, A. J. B., Brock, T. D. (1980). Anaerobic methane oxidation: occurrence and ecology. Appl. environ. Microbiol. 39: 194-204

ZoBell, C. E. (1938). Studies on the bacterial flora of marine bottom sediments. J. sedim. Petrol. 8: 10-18

Zuberer, D. A., Silver, W. S. (1978). Biological dinitrogen fixation (acetylene reduction) associated with Florida mangroves. Appl. environ. Microbiol. 35: 567-575

This paper was presented by Professor S. P. Meyers; it was accepted for printing on October 14, 1982 